\title{
Thematic Mapping in Siwani Area, District Bhiwani using Remote Sensing and Gis
}

\author{
Priyanka
}

Research Scholar (MDU, Rohtak, Haryana)

\begin{abstract}
The terms "land use" and "land cover" are often used simultaneously to describe maps that provide information about the types of features found on the earth's surface (land cover) and the human activity that is associated with them (land use). The main objectives in the present study are to prepare base map, land usel land cover \& geomorphology map of the study area to accustom with GIS techniques for preparing maps, to acquaint with global positioning system (GPS). The study area constitutes a part of Siwani block of Bhiwani district, Haryana. The area lies between $28^{\circ} 55^{\prime} \mathrm{N}$ to $29^{\circ} 10^{\prime}$ latitudes and $75^{\circ} 30^{\prime}$ to $75^{\circ} 45 E^{\prime}$ longitudes. Its boundary in the north by Hisar district, in the west by Churu district of Rajasthan and the east and south by parts of Siwani block. In the present study image processing and visual interpretation technique were employed to carry out Land use/Land cover classification using digital data and standard False Colour Composite (FCC) paper print of Indian Remote Sensing satellite. Digital data of IRS - ID, LISS-III ,2011. Geocoded standard False Colour Composite (FCC) paper print of IRS - 1D, LISS-III acquired on March, 2006. Survey of India toposheet No. 44P/9 on 1:50,000 scale. Reports and other related material. An exhaustive ground truth was done to confirm the interpreted land use/land cover maps. For the field survey base maps were prepared of Bhiwani district. In conclusion based upon the standard image characteristics like texture, tone, shape, size, association, pattern and site etc. the visual interpretation of IRS imagery, land use land cover map was prepared to identify and to map the land cover/ land use details of the study area. In this we found different LU/LC characteristics like rural, urban, fellow land, agriculture land, forest plantation, waste land etc. The study area has been divided into major physiographic units i.e., aeolin plain, sand dunes, sand dune complex and interdunal valley.
\end{abstract}

\section{OBJECTIVES OF THE STUDY}

- To prepare base map, land use/ land cover \& geomorphology map of the study area.

- To acquaint with global positioning system (GPS) and its application.

\section{Discription OF THE STUDY AREA}

\subsection{Location and Extent}

The study area constitutes a part of Siwani block of Bhiwani district, Haryana. The area lies between $28^{\circ} 55^{\prime} \mathrm{N}$ to $29^{\circ} 10^{\prime}$ latitudes and $75^{\circ} 30^{\prime}$ to $75^{\circ} 45 \mathrm{E}^{\prime}$ longitudes. It is bounded in the north by Hisar district, in the west by Churu district of Rajasthan and the east and south by parts of Siwani block shown in Fig.1.

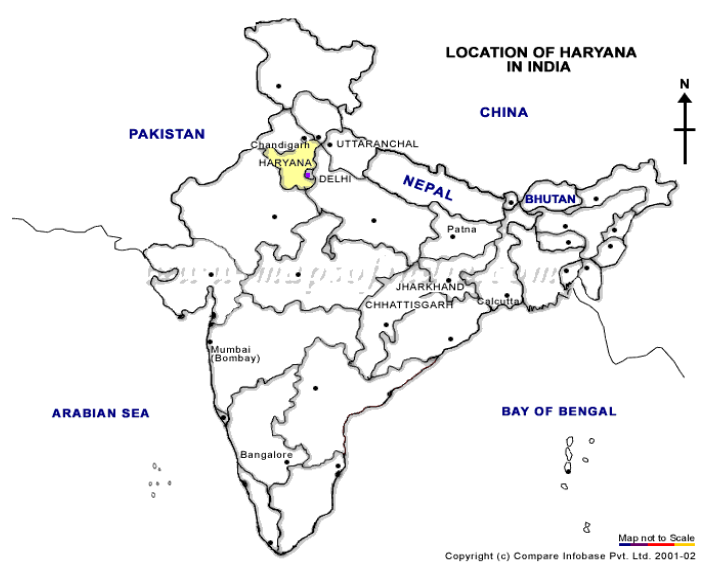




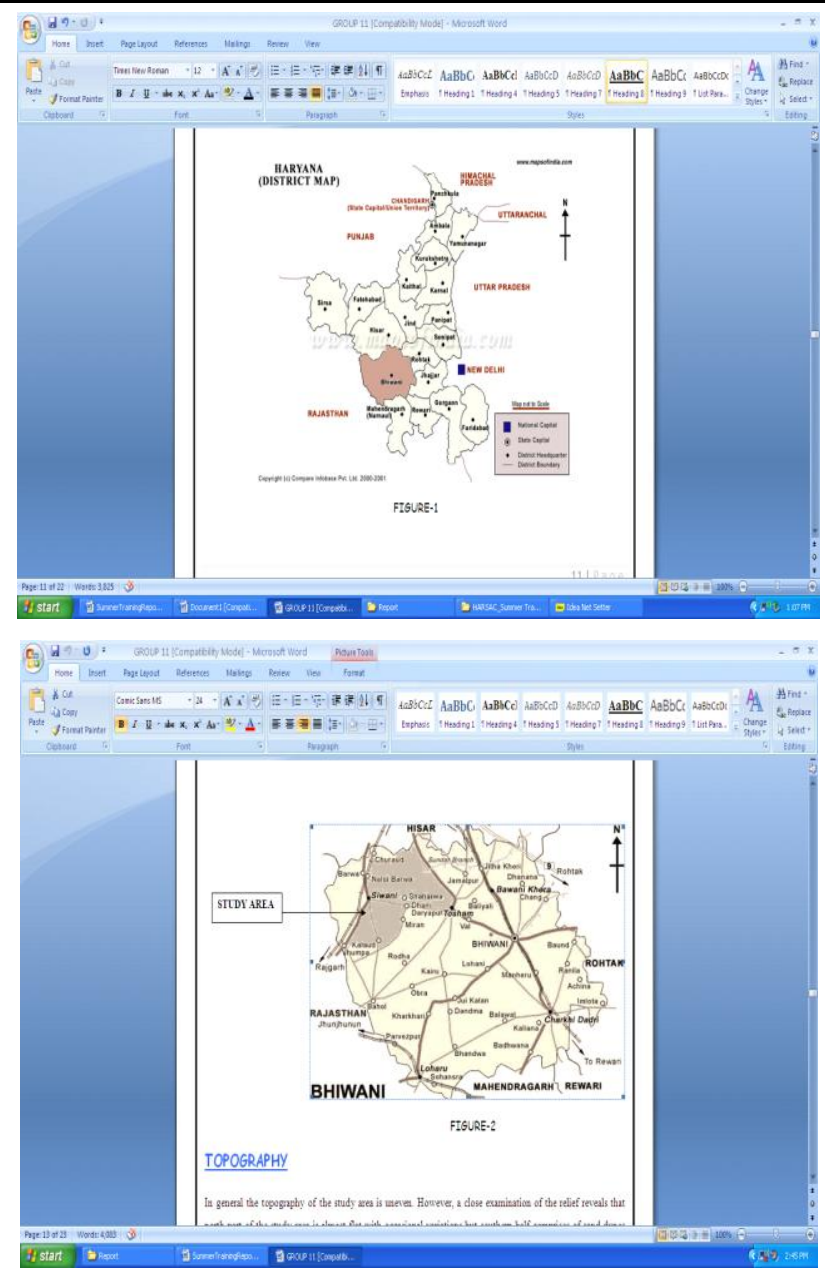

Fig1. Study area

\subsection{Physical Settings}

Topography of the study area is uneven. However, a close examination of the relief reveals that north part of the study area is almost flat with occasional variations but southern half comprises of sand dunes and inter-dunal sandy area.The climate of the study area is characterized by extreme climatic conditions with hot summer and cold winter with scanty rainfall. The temperature ranges from $5^{\circ} \mathrm{C}$ to $45^{\circ} \mathrm{C}$. Maximum temperature often touches $45^{\circ} \mathrm{C}$ by the end of June. January is the coldest month with average monthly minimum temperature of $1.50^{\circ} \mathrm{C}$ and average monthly maximum temperature of $25.54^{\circ} \mathrm{C}$. The average annual rainfall of the study area is $284 \mathrm{~mm}$.

\section{DAta baSe AND Methodology}

\subsection{Methodology}

In the present study image processing and visual interpretation technique were employed to carry out Land use/Land cover classification using digital data and standard False Colour Composite (FCC) paper print of Indian Remote Sensing satellite.

- First of all Satellite data selection, Understanding different land use/ land cover classes, Preparation of base map from SOI Toposheet, Interpretation, Visual interpretation of the remote sensing data by using the usual clues such as shape, size, pattern, texture, tone .

- Scanning/digitization of maps which are undated during the field survey, Area calculation, Land use/ land cover analysis and after that preparation of final land use/land cover \& geomorphological map and tables.

\subsection{Data Used}

\subsubsection{Satellite Data}

- Digital data of IRS - 1D, LISS-III of path 90 and Row 50 acquired on March, 2011. 
- Geocoded standard False Colour Composite (FCC) paper print of IRS - 1D, LISS-III acquired on March, 2006.

\subsubsection{Auxiliary Data}

- Survey of India toposheet No. 44P/9 on 1:50,000 scale

- Reports and other related material

\subsection{Software Used}

\subsubsection{Erdas Imagine 9.3}

ERDAS IMAGINE is a raster graphics editor and remote sensing application designed by ERDAS, Inc. Moreover this software was used for preparation of final images to facilitate the study. This software was used for layer stacking, cropping, Georeferencing and Mosaicing of satellite data.

\subsubsection{ARC/MAP 9.3}

Arc Map provides all tools of need to put the data on a map and display it in an effective manner. The software was used to prepare land use/land cover maps of the study area.

Ms - Office: MS - Office was used for report writing, making tables and graphs.

Preparation of base Map: To transfer the land use details, a base map was prepared on 1:50,000 scale using survey of India topographic sheets of study area. Information including roads, canals and location of villages were traced on the base map so that alignment problems of tracing with satellite data could not take place. Base map of present study shown in Fig. 2.

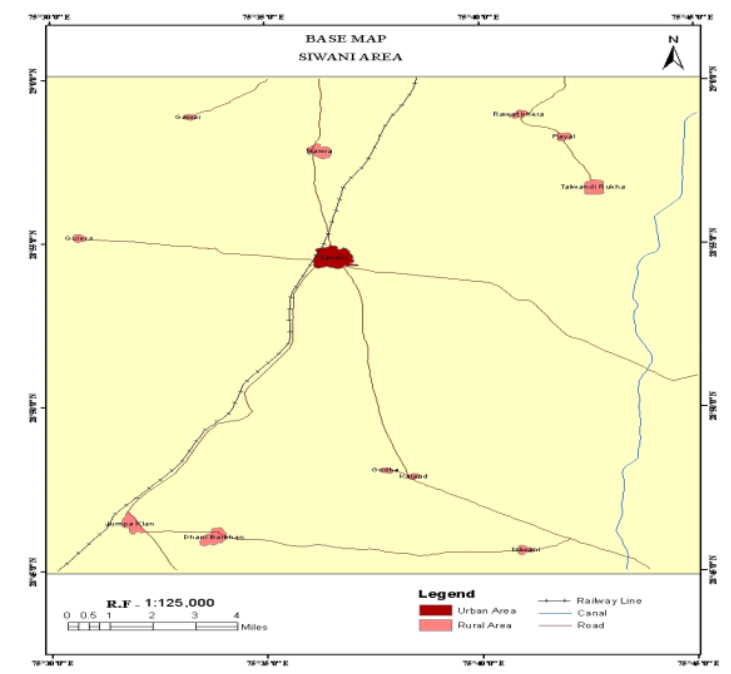

Fig.2

\subsection{Visual Interpretation of Data}

The interpretation was based on shape, size, tone/colour, texture, and pattern, and location aspects of the particular feature on the satellite imagery.

\subsection{Digital Data Loading \& Stacking}

The digital data acquired from NRSC, Hyderabad in BIL format was imported from the computer discs (CDs). This data was in the form of three layers of different bands. The layers were stacked and FCCs were generated using the standard routines from the ERDAS Imagine 9.3 software in img format. The digital data was then displayed on the display terminal in form of FCCs and enhancements were done to observe quality and coverage of the data.

\subsection{Scanning}

Scanning is the process of translating photographs into a digital form that can be recognized by a computer. It is the act of systematically moving a finely focused beam of light or electrons over a surface in order to produce an image of it for analysis or transmission. The base map, landuse/landcover and geomorphological maps of study area were prepared from SOI toposheet and FCC. These scanned maps were then rectified with SOI ticks after that georefrencing then mosaicing was done to obtain one single image from two overlapping images covering the areas. . After that maps were rectified 


\subsection{Ground Truth Data Collection}

An exhaustive ground truth was done to confirm the interpreted land use/land cover maps. Ground truth data was collected in the form of GPS points using handheld GPS. For the field survey base maps were prepared of Bhiwani district. The doubtful areas were specially checked and marked on the pre-field interpreted maps. Various drop structures, gully plug areas, check dams were marked with the location information recorded using Garmin handheld GPS. Ground truth particularly of the ambiguous features, was carried out on the selected locations of ambiguous features. The prefield maps were modified by incorporating field observations. Details of ground control points are shown in Table 1.

Table1. Ground control points

\begin{tabular}{|l|l|l|}
\hline Sr no. & Name & Location \\
\hline 1 & Canal crossing on NH 65 Chaudharywas & $28^{\circ} 59^{\prime} 32.1^{\prime \prime} \mathrm{N} \mathrm{75} 36^{\prime} 21.3^{\prime \prime} \mathrm{E}$ \\
\hline 2 & Barwa Village & $28^{\circ} 57^{\prime} 557^{\prime \prime} \mathrm{N} 75^{\circ} 35^{\prime} 599^{\prime} \mathrm{E}$ \\
\hline 3 & Railway Road Crossing Near Siwani & $28^{\circ} 55^{\prime} 021^{\prime \prime} \mathrm{N} 75^{\circ} 36^{\prime} 81^{\prime \prime} \mathrm{E}$ \\
\hline 4 & Sand dunes, Near Siwani & $28^{\circ} 55^{\prime} 21^{\prime \prime} \mathrm{N} 75^{\circ} 36^{\prime} 817^{\prime \prime} \mathrm{E}$ \\
\hline 5 & Sandy area with Light plantation;jhumpa & $28^{\circ} 46^{\prime} 17^{\prime \prime} \mathrm{N} \mathrm{75} 38^{\circ} 16^{\prime \prime} \mathrm{E}$ \\
\hline 6 & Waterbody, Isharwal & $28^{\circ} 46^{\prime} 98^{\prime \prime} \mathrm{N} 75^{\circ} 32^{\prime} 318^{\prime \prime} \mathrm{E}$ \\
\hline 7 & Agricultural Area ,Miran & $2848^{\prime} 543^{\prime} \mathrm{N} 7544^{\prime} 95^{\prime \prime} \mathrm{E}$ \\
\hline 8 & Water Logged Area, Saharwa & $28^{\circ} 54^{\prime} 273^{\prime \prime} \mathrm{N} 75^{\circ} 44^{\prime} 173^{\prime} \mathrm{E}$ \\
\hline
\end{tabular}

\subsection{Final Image Interpretation \& Analysis}

As the doubtful areas in the pre-field interpreted maps were checked during the ground truth accordingly these maps were modified. After due corrections, attributes were attached and final land use/ land cover maps were prepared for the district.

\subsection{Map Composition}

The final maps were composed in Arc Map 9.3 software to display the different layers of the extracted information in an effective manner for this purpose, the different layers of extracted information in .shp format were loaded in Arc Map and the maps were composed having legend to represent the categories of different classes these maps were then exported to JPEG format to represent in the final output.

\section{ReSUlts \& Discussion}

\subsection{Land use/ Land Cover}

Based upon the standard image characteristics like texture, tone, shape, size, association, pattern and site etc. the visual interpretation of IRS imagery, land use land cover (LU/LC) map was prepared ( Fig-3) to identify and to map the land cover/ land use details of the study area (Table 2).

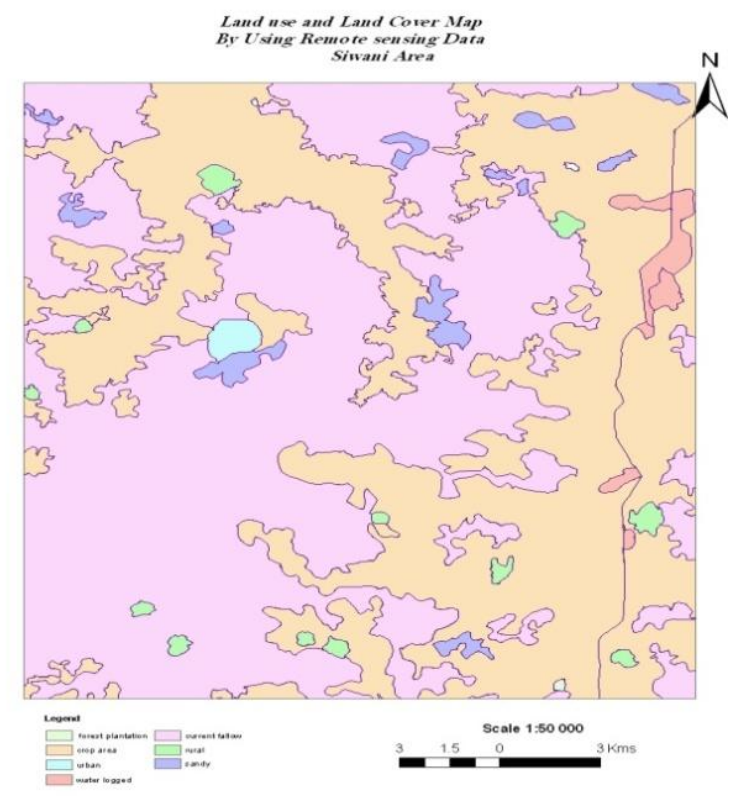


Table2. Land use/ Land cover classification and area

\begin{tabular}{|l|l|l|}
\hline Sr. no & Categories & Area In Sq. KM. \\
\hline 1. & Rural & 9.0752 \\
\hline 2. & Urban & 1.9718 \\
\hline 3. & Crop Area & 261.4135 \\
\hline 4. & Current Fallow & 383.8431 \\
\hline 5. & Forest Plantation & 0.1318 \\
\hline 6. & Sandy Area & 10.7371 \\
\hline 7. & Water Logged & 5.8355 \\
\hline & Total & 673.008 \\
\hline
\end{tabular}

\subsection{Built Up Land}

Built up land is divided into rural and urban categories. Hisar was identified as an urban centre in the study area. Villages that are homogeneously distributed and associated with agricultural land were also identified and mapped.

Agricultural Land: This category land primarily used for farming and for production of food, fiber and other commercial and horticulture crops. Bajara, Jwar and Millets are major Kharif crops in this area.

Fallow Land: This unit of land is temporarily allowed to rest for one season or more. In this area majority of southern parts belongs to this category due to lack of irrigational facilities and sand dunal topography.

Forest Plantation: The study area consists of semi arid deserted type of vegetation cover. These plantations mainly done under social forestry plantation programmes. The species found in this area are Jand, Kikar. Beri, Jal etc.

Wasteland: Three categories of wasteland were found in this area namely, sandy area, degraded pastures and water logged land, sandy area are identified on the imagery. Waterlogged areas with dark tone on imagery are confined adjacent of Hisar town. Degraded pastures are located around rural settlements in village common land. The land has been degraded due to lack of soil and water conversation measures over the ages. The area is very suitable silvi-pasture development.

Physiography: The study area has been divided into major physiographic units i.e., Alluvial Plain, Sand Dunes, Sand Dune Complex and Interdunal Valley fig.4 (Table 3).

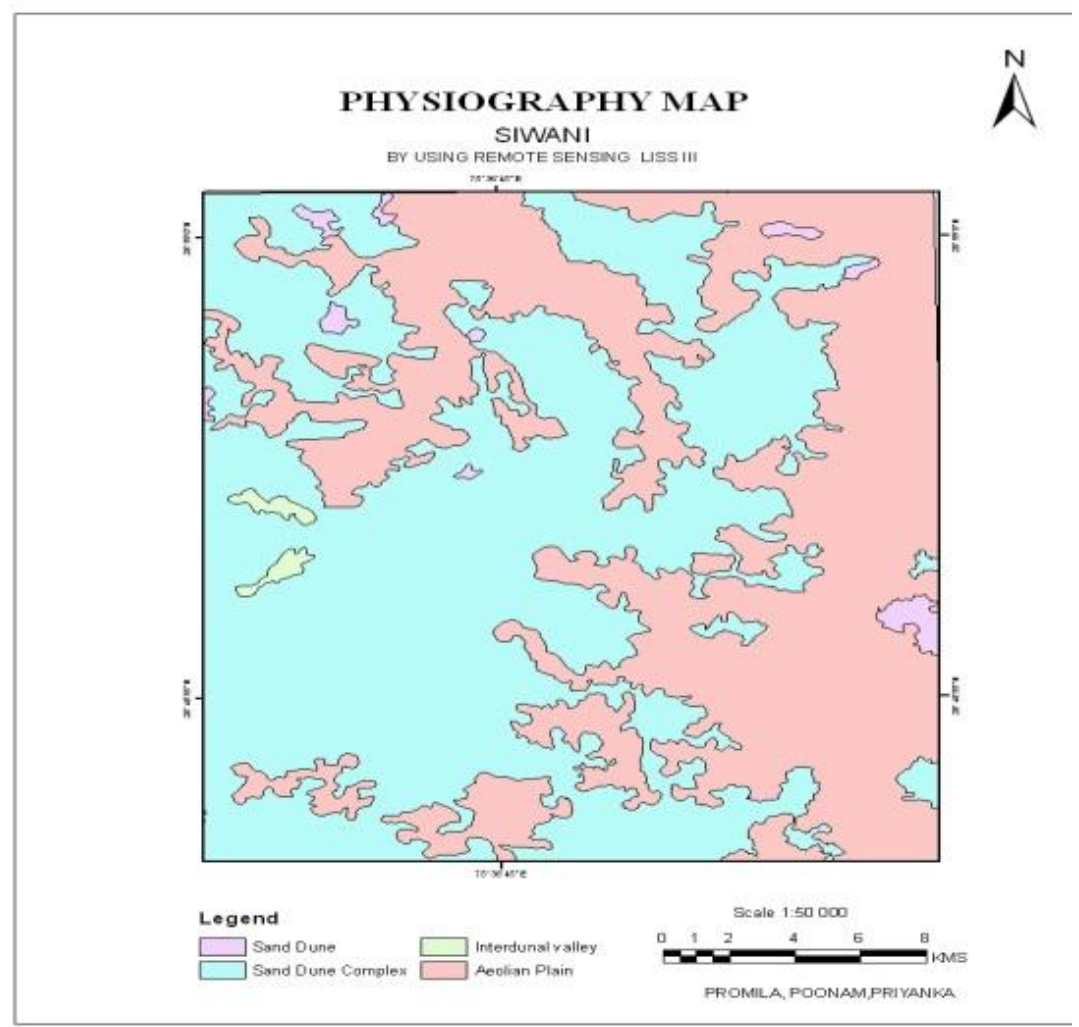


Table5. Geomorphology classification and area

\begin{tabular}{|l|l|l|}
\hline Sr. no. & \multicolumn{1}{|c|}{ Type of Area } & Area in sq. km. \\
\hline 1. & Sand Dunes & 8.23 \\
\hline 2 & Sand Dune Complex & 387.99 \\
\hline 3 & Interdunal Valley & 3.512 \\
\hline 4 & Aeolin Plain & 277.14 \\
\hline & Total & 676.87 \\
\hline
\end{tabular}

\section{REFERENCES}

[1] Arya, V. S. and Reena Devi (2008). Digitization of cadastral maps and their integration with high resolution satellite data for landuse/ land cover mapping - A case study. Post Graduate Diploma dissertation, HARSAC, Hisar.

[2] Arya, V.S., Arya, Sandeep, Khatri, S.S., Sharma Prem Prakash, Singh Vijay, Sharma Heena, Singh Hardev and Hooda, RS (2006). Updated wasteland atlas of Haryana. HARSAC Atlas.

[3] Ambala, (2012) Haryana Government Town and Country Planning Department Notification The 6th September, 2012.

[4] Arvind C. Pandy and M. S. Nathawat,(2006) 'Land Use Land Cover Mapping Through Digital Image Processing of Satellite Data - A case study from Panchkula, Ambala and Yamunanagar Districts, Haryana State, India'.

[5] Bhardwaj, P., and Kumar, S., (2012) 'Urban Expention and Land Use Change Analysis of Karnal City in Haryana: A Study Based on Open Source Satellite Data'. International Journal of Emerging Technology and Advanced Engineering, 2(12):182-186.

[6] Saini, S.S., and Kaushik, S.P., (2011) 'Land Use Changes in Haryana Sub Region of Chandigarh Periphery Controlled Area - A Spatio - Temporal Study'. Institute of Town Planners, India Journal, 8(4):96-106. 